\title{
Exchange Rate Pass-Through to Import Prices, Inflation and Monetary Policy in Nigeria
}

\author{
M. O. Fatai (Corresponding Author) \\ Department of Economics \\ Obafemi Awolowo University, Ile-Ife, Nigeria \\ Tel: 234-80-3325-8126_E-mail: fatism_ecn@yahoo.com
}

T. O. Akinbobola

Department of Economics

Obafemi Awolowo University, Ile-Ife, Nigeria

Tel: 234-80-3717-2271_E-mail: tbobola@yahoo.co.uk

Received: May 18, 2015

Accepted: May 28, 2015

Published: May 30, 2015

doi:10.5296/ifb.v2i1.7914

URL: http://dx.doi.org/10.5296/ifb.v2i1.7914

\begin{abstract}
The study investigates the impact of Exchange Rate Pass-through (ERPT) to import prices, Inflation, and monetary policy in Nigeria. Secondary data were used. The data covered the period of 1986-2012. Annual data on Nominal Effective Exchange Rate Index (NEER), Import Prices (IMP), Interest Rate (ITR), Money Supply (MS) and Inflation (INF) were sourced from the publication of the Central Bank of Nigeria (CBN) and Oil Price Index (OPI) were sourced from the World Development Indicators (WDI) published by the World Bank. The study applied Six-Variable VAR Model to estimate the Impulse Response Function (IRFs) and Variance Decomposition (VDCs). Based on SVAR analysis the study found that ERPT in Nigeria during the period under review is moderate, significant and persistent in the case of import prices and low and short lived in the case of inflation. The fact is that, ERPT was found to be incomplete and has useful implication to policymakers, especially in the design and implementation of exchange rate and monetary policy. Thus policy makers should take into account the incomplete response of import prices when they decide to devalue the currency so as to improve trade balance irrespective of several other factors which might determine the effectiveness of exchange rate policy (such as supply factors, elasticity of foreign and domestic demand, availability of substitutes etc ). To achieve this, the increased
\end{abstract}


role of $\mathrm{CBN}$ will definitely require a carefully developed monetary policy and a strengthening of its institutional capacity.

Keywords: Exchage Rate Pass-through, VAR, Import prices, Inflation, Monetary policy. 


\section{Introduction}

In the contemporary world where international trade plays a crucial role for economic development, countries, more often than not, depreciate or devalue their currency to be more competitive and reap the fruit of bilateral and multilateral trade with their partners. The exchange rate movement has been identified as one of the instruments determining countries competitiveness in the world market. As it guides investors on the best way they can strike a balance between their trading partners, and investing at home or abroad (Barhoumi, 2007). In addition, it is essential to manage domestic inflation rate which can also be influenced by the movement in the exchange rate.

The channel through which exchange rate affects domestic inflation rate is of crucial importance to policy makers in order to know the appropriate monetary policy variables which considers the effect of exchange rate movement on inflation. Beyond policy implications, economists have long been interested in investigating the influence of exchange rate and its volatility on both domestic price level and output. This analysis can be done through Exchange Rate Pass-Through (ERPT).

According to Mumtaz, Oomen and Wang (2006), exchange rate pass-through is defined as-" "the percentage change in local currency import prices following a one percent change in the exchange rate between importing and exporting countries." Indeed, Garcia and Restrepo (2001) identified three transmission channels through which the exchange rate impulses to domestic inflation: (1) a direct effect through prices of imported goods on the Consumer Price Index (CPI); (2) an effect through prices of imported intermediate goods; and (3) an effect through price setting and expectations which includes the expected responses of monetary policy.

Understanding the rate at which Exchange Rate Pass-through (ERPT) to import prices is important for different reasons, which includes; If Exchange Rate Pass-Through is low it gives a freedom for the monetary authority to apply its monetary policy independently (Choudhri \& Hakura, 2001). However, according to Bussière (2007), change in exchange rate affects the price of imports, in return, import prices will affect the domestic inflation. However, the degree of ERPT also has important implications for expenditure switching effect and hence current account adjustment, which results from the exchange rate movements. If the extent of pass-through is high, the exchange rate changes will change the relative prices of tradables and non-tradables, so that the adjustments in trade balances will be relatively prompt (Ito \& Sato, 2006). Exchange rate pass-through may be lower when exporters try to maintain local market share, even if nominal exchange rate variability is high (Froot \& Klemperer, 1989). Campa and Goldberg (2005) maintained that when exchange rate changes, foreign firms can choose to pass exchange rate changes fully to their selling prices in export markets, that is, complete pass-through to bear exchange rate changes to keep selling prices unchanged. In other words, the exchange rate pass-through to import and consumer prices is an important link in the monetary policy transmission. Fluctuation in the exchange rate value (appreciation or depreciation) will not only result in major changes in the prices of imported goods, but also imported inputs, which affects the cost of the finished goods. 


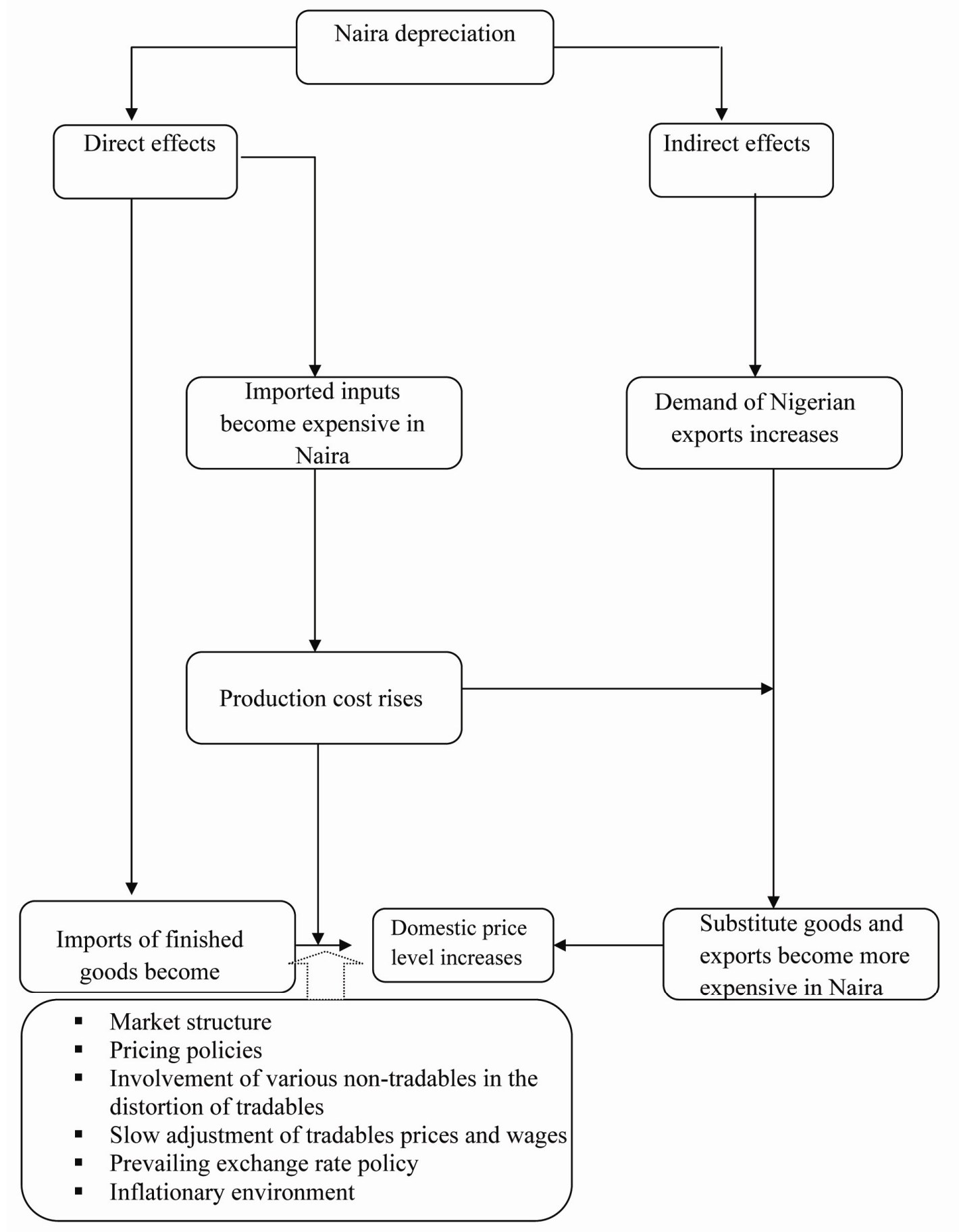

Figure 1. Exchange rate pass-through mechanism to domestic prices in Nigeria

Source: Aliyu et al. (2008).

Given that Nigeria is a developing economy and also open to external trade with other countries, her economy is not in any case impervious to external shocks. More specifically, as a result of its considerable degree of openness to foreign trade, Nigeria's domestic price level is susceptible to exchange rates volatility (depreciation or appreciation) and also changes in 
import prices (Aliyu, Yakub, Sanni, \& Duke, 2008). Figure 1 shows the exchange rate pass-through mechanisms; domestic prices can be influenced through two main channels-direct and indirect. As epitomized, with depreciation in the value of naira, domestic prices are affected through direct changes in the prices of imported finished goods and imported inputs. These goods simply become expensive in naira terms. Eventually, as a result of higher costs of imported raw materials and capital goods, marginal costs of production increases and hence, domestically produced goods become more expensive.

Meanwhile, the extent, speed and magnitude of exchange rate pass through to import and consumer prices of course, depend on some factors. Among other factors are domestic market structures, pricing policies, inflationary environment and involvement of non-tradables in the distribution of tradables. These factors either deepen or lessen the impact of exchange rate volatility on the domestic prices.

Today, many economies focus attention on exchange rate policy for many reasons. As a tool of correcting internal and external imbalances as well as an instrument for improving the efficiency of resource allocation, and stabilization processes. This is particularly so for imported commodities and those produced within an economy whose intermediate inputs and raw materials depend heavily on import such as Nigerian economy. The real exchange rate measures international exchange of goods and services, the competitiveness of an economy to international trade and ensures viable balance of payment position.

The discussion above makes it imperative for policy makers to look at the implications of these developments and the extent of the exchange rate pass-through on import and consumer prices in Nigeria. There is still a paucity of research on the empirical estimates of pass-through for small open and developing economy. Most of the studies have focused on the U.S, Germany, Canada, Belgium, Italy, Austria, Switzerland, Ireland (Goldberg \& Knetter, 1997; Feenstra, 1989; McCarthy, 2000; Marazzi \& Vigfusson, 2005); Asia (Menon, 1995; Anderton, 2003; Campa \& Goldberg, 2004; Campa et al., 2005; Gagnon \& Ihrig, 2004), and Latin America (Garcia \& Restrepo, 2001) leaving a glaring gap for developing countries. There is also a growing literature of ERPT on emerging market economies, including cross-country comparisons as in Choudhri and Hakura (2006). Few empirical studies on some Sub-Saharan Africa (SSA) countries includes; Akofio-Sowah (2009) for South Africa, Kiptui, Ndolo and Kaminchia (2005) for Kenya, and Oladipo (2007), Oladipo (2012) and Aliyu et al. (2008) for Nigeria but these cannot be generalized for all SSA countries because of their peculiar problems and economic conditions which are country specific and therefore responsible for the heterogeneous nature of pass-through estimates as obtained in the study by Barhoumi (2005) on few developing countries. Thus, the need for more country-specific studies on the subject matter so as to redress the imbalance in the country specific study coverage by presenting a cross examination on the chain reaction caused by the mixed results of the previous empirical studies on ERPT in Nigeria. Specifically, the nature of the ERPT; that is, is it complete? While some authors concluded that ERPT is incomplete, some have it that there is zero pass-through and also to further assist in the formulation of appropriate monetary policies. 


\section{Literature Survey}

The vast body of literature concerning exchange rate pass through (ERPT) can be broadly classified as those done at micro level and those which are conducted at macro level. Studies conducted at micro level focused on examining ERPT into disaggregated import prices of specific domestic industries. On the other hand, those conducted at macro level examined ERPT into aggregate price indices and can be further classified in two categories. The first category examines the degree of pass-through into aggregate import prices while the second one analyzes pass-through into the consumer prices. Among these, some are conducted on country level while others are cross country comparisons. In general, previous studies try to analyze the following basic issues concerning ERPT: 1) estimate the degree of pass-through to various price indices 2) try to explain why pass-through is incomplete and why it is declining 3) whether it is a macro or micro phenomenon 4) and why pass-though is lower for domestic prices than import prices.

Goldberg and Knetter (1997) found that the response of domestic prices to exchange rate movement is only partial in US. On average only around 60 percent of exchange rate changes are passed on to import prices in the US. However, the response of domestic US price to exchange rate fluctuations vary from sector to sector and a considerable portion of the muted price responses seem to emanate from changes in markups on export prices. Similarly Yang (1997) studies ERPT in US manufacturing industries and its cross-sectional variation. The study shows that pass-through is incomplete (on average 32 percent in the short run and 42 percent in the long run) and varies across industries. In the cross-sectional study ERPT is found to be higher in industries with a higher degree of product differentiation and a lower elasticity of marginal cost. The study also shows a negative relationship between import share and ERPT. Recently, Marazzi and Vigfusson (2005) investigates ERPT to import price in US. They found a sustained decline in ERPT to US import prices, from above 0.5 during the 1980 s to somewhere in the neighborhood of 0.2 during the last decade (1993-2004).

McCarthy (2000) presents a comprehensive study of ERPT on the aggregate level for a number of industrialized countries which include the US, Germany, Japan, France, the United Kingdom, Belgium, Netherlands, Switzerland and Sweden. He estimates a VAR model using import, producer and consumer price data from 1976 till 1998. The findings of the study show that exchange rates and import prices have a modest effect on domestic price inflation over the post-Bretton Woods era. The pass-through is found to be stronger in countries with a larger import share. The rate of pass-through is, furthermore, shown to be positively correlated with the openness of the country and with the persistence of and exchange rate change, and negatively correlated with the volatility of the exchange rate.

Gagnon and Ihrig (2004) explore the relationship between ERPT, inflation and monetary policy credibility in twenty industrial countries between the period 1971 and 2003. In addition to using a cross-sectional approach, as do Choudhri and Hakura (2001) and Devereux and Yetman (2002), they also test whether pass-through declined in each country in the sample following a change in the inflation regime. The study shows that countries in which either the level or the standard deviation of inflation declined substantially from the 
first to the second sub-sample tended to have large declines in estimated rates of pass-through. Finally, they test a more direct connection between monetary policy and pass-through by estimating a Taylor-type monetary policy rules using the forward-looking specification of Clarida et al. (1998). In a cross-country regression using the full sample, they find no statistically significant relationship between estimated ERPT and the estimated monetary policy parameters. However, there is a statistically significant relationship between changes in estimated pass-through across the two sub-samples and changes in monetary policy parameters. In general the study concluded that the decline ERPT in industrialized countries is attributed to change in monetary policy towards stabilizing inflation.

Proceeding to studies which are conducted on developing countries, Rowland (2003) examines ERPT for Colombia using Vector Error Correction Model (VECM) and found ERPT to be incomplete both to import and domestic prices. He found that import prices respond quickly to an exchange rate change (80 percent within 12 months) while pass-through is modest for producer prices ( 28 percent) and very limited for consumer prices (less than 15 percent). An exchange rate shock does, therefore, only have little impact on consumer price inflation. Ito and Sato (2006) analyze ERPT in post crisis Asian economies and found that the degree of pass-through to exchange rate shocks varies across the different price indices: the pass-through effect is the largest on the import price index, the second on PPI and the smallest on CPI. The degree of exchange rate pass-through to import prices was quite high in the crisis-hit countries while the pass-through to CPI was generally low, with a notable exception of Indonesia.

Zorzi et al. (2007) estimate the magnitude of ERPT in emerging economies. They found that ERPT is higher for import prices than for consumer prices implying that degree of pass through declines along the pricing chain. Also their analysis partly overturns the conventional wisdom that ERPT is always considerably higher in "emerging" than in "developed" economies. Particularly, they found that in low inflation emerging economies (notably the Asian economies) pass-through to consumer prices is rather low just like advanced countries (such as US and Japan) which are included in their study.

Several studies analyzed ERPT in relation with monetary policy behavior and inflationary environment which was first emphasized by Taylor (2000). A number of recent studies find some empirical support for the relationship but the evidence is not conclusive. Choudhri and Hakura (2001) test Taylor (2000) hypothesis for 71 countries (where the sample contains set of developed, emerging and developing countries) for the period between 1979 and 2000. In their empirical analysis the long-run inflation rate is used as an indicator of the aggressiveness of monetary policy response to short-run price fluctuations. The use of this proxy is motivated by the plausible assumption that regimes which make a stronger effort in stabilizing the short-run inflation rate are also able to maintain low inflation rates in the long run. They found strong evidence of a positive correlation between ERPT and average inflation for a large sample of developed and emerging market economies. They also explored the influence of other variables, but found that average inflation dominates in explaining differences in observed ERPT. 
Akofio-Sowah (2009) examined the exchange rate pass-through for 15 Sub-Saharan Africa countries and 12 Latin American countries over the period 1980-2005 and found an incomplete pass-through. Moreover Akofio-Sowah supported the Taylor proposition of low inflation environment haven low level of exchange rate pass-through. By applying VAR model, Belaisch (2003), found partial exchange rate pass through in Brazil. He found exchange rate pass-through of $6 \%$ and $17 \%$ for consumer price, $34 \%$ and $120 \%$ for whole sale price and $27 \%$ and $53 \%$ for general price for the first and fourth quarter respectively. The reason for the decline in pass-through rate are; firms preferred to shrink there mark-up instead of completely passing the exchange rate burden to consumers, availability of substitute for imported items and the perception of temporary depreciation.

Aliyu et al. (2010) investigates the degree of ERPT to import and consumer prices in Nigeria between 1986 and 2007 on the basis of VECM. Using the impulse response function, they establish the degree of pass-through to import and consumer prices in Nigeria during the period under review to be incomplete (low), persistent and significant. They also found that ERPT is slightly higher in the import than in the consumer prices which suggest that pass through declines along the pricing chain in Nigeria. A one percent shock to exchange rate, for instance, results in 14.3 and 10.5 percent pass-through effect to import and consumer prices four quarters ahead, respectively. Oladipo (2012) used Leontief Input-Output Model to test the empirical analysis of sectoral exchange rate pass-through effects on a small open economy in Nigeria during the period of 1970-2010. The empirical result reveals that, sectoral dependence on imports varies across sectors and show evidence of incomplete pass-through at varying degrees across sectors.

\section{Research Method (Theoretical Framework)}

The theoretical underpinning for which the relationship between prices and exchange rate is based evolved from the doctrine of Purchasing Power Parity (PPP) an offshoot of the Law of One Price (LOP) with the assumptions that there are no trade barriers and transport cost. Following Krugman and Obstfeld (2003), PPP states that an exchange rate between two countries should be equal to the ratio of the price level in one country to the price level in the other country that is, relative prices. Akofio-Sowah (2009) explains it mathematically by:

$$
P=E P^{*}
$$

Where $\mathrm{P}$ is the domestic price, $\mathrm{P} *$ is foreign currency price and $\mathrm{E}$ is exchange rate defined as the ratio of domestic currency to foreign currency. The regression of the above equation by taking the natural log of the above variables gives;

$$
p=\alpha+\beta p^{*}+\lambda e+\varepsilon
$$

Where: $p, e$ and $p^{*}$ are the natural logarithm of $\mathrm{P}, \mathrm{E}$ and $\mathrm{P}^{*}$ respectively.

If we assume that PPP holds in equation (2), $\alpha=0, \beta=1$ and $\lambda=1$. Hence there will be a complete Exchange Rate Pass-Through. But in most cases, this does not hold that is there is incomplete pass through. One possible explanation is the presence of product differentiation and the other justification might be imperfect market competitions where producers want to 
maintain their market share. Dornbusch (1987) justifies the incomplete Pass-Through simply because firms not only adjust the cost structure (prices) but also their mark-up when there is an exchange rate shock.

Based on this general background, we specify a six variable VAR model which includes Oil Price Index, Interest rate, Money Supply, Nominal Exchange rate, Import Price, and Inflation. Following McCarthy (1999); Smets and Wouters (2002); Hahn (2003); Ito and Sato (2006), Bhattacharya et al. (2011) and others as shown in equation (3).

$$
\mathrm{Y}_{\mathrm{t}}=\alpha+\sum^{p}{ }_{i=1} \beta_{\mathrm{i}} \mathrm{Y}_{\mathrm{t}-1}+\mathcal{E}_{\mathrm{t}}
$$

Where $Y_{t}$ represents the vector of endogenous variables (Oil Price Index (OPI), Nominal Effective Exchange Rate Index (NEER), Import Price (IMP), Interest Rate (ITR), Money Supply (MS) and Inflation (INF)). $\alpha$ is a vector of constants, $\beta_{i}$ refers to the matrices of autoregressive parameters and $\varepsilon_{t}$ is a vector of white noise processes.

Therefore, $y_{t}$ can be written as:

$$
y_{t}=[\mathrm{OPI}, \mathrm{MS}, \mathrm{NEER}, \mathrm{IMP}, \mathrm{ITR}, \mathrm{INF}]
$$

\subsection{Model Specification}

Based on the theoretical framework, The baseline empirical model is estimated as a VAR with six endogenous variables. The SVAR form representation of the model may be written as:

$$
B_{0} y_{t}=B_{1} y_{t-1}+\ldots \ldots+B_{p} y_{t-p}+\varepsilon_{t}
$$

Where $y_{t}=[\Delta \mathrm{OPI}, \Delta \mathrm{MS} \Delta \mathrm{NEER}, \Delta \mathrm{IMP}, \Delta \mathrm{ITR}, \Delta \mathrm{INF}]$ vector of $\mathrm{k}=6$ variables. $B_{0}$ is an invertible $(n \times n)$ matrix of coefficients of contemporaneous relations on the endogenous variables; $B_{i}$ 's are $(n \times n)$ matrices which captures dynamic interactions between the $k$ variables in the model, $\varepsilon_{t}$ denotes a mean zero $(\mathrm{n} \times 1)$ vector of structural error terms, also referred to as a structural innovation or structural shock and $p$ is the number of lags. Equivalently the model can be written more compactly as:

$$
B(L) y_{t}=\varepsilon_{t}
$$

Where $(L)=B_{0}-B_{1} L+B_{2} L^{2} \ldots+B_{p} L^{p}$ is the autoregressive lag order polynomial. The variance-covariance matrix of the structural error term is typically normalized such that: $\mathrm{E}\left(\varepsilon_{t}\right.$ $\left.\varepsilon^{\prime}{ }_{t}\right)=\Sigma \varepsilon=\mathrm{I} k$.

In order to allow estimation of the structural model we first need to derive its reduced-form representation (since the structural model is not observable). This involves expressing $y_{t}$ as a function of its lags. To derive the reduced form representation, we pre-multiply both sides of the structural VAR representation by $B_{0}{ }^{-1}$ :

$$
B_{0}^{-1} B_{0} y_{t}=B_{0}^{-1} B_{1} y_{t-1}+\ldots \ldots+B_{0}^{-1} B_{p} y_{t-p}+B_{0}^{-1} \varepsilon_{t}
$$


Hence, the same model can be represented as:

$$
y_{t}=A_{1} y_{t-1}+\ldots \ldots+A_{p} y_{t-p}+u_{t}
$$

Where:

$A_{i}=B_{0}^{-1} B_{0}, \mathrm{i}=1, \ldots, \mathrm{p}$, and $u_{t}=B_{0}^{-1} \varepsilon_{t}$. Equivalently the model can be written more compactly as:

$$
A(L) y_{t}=u_{t}
$$

Where $B(L)=I-A_{1} L+A_{2} L^{2} \ldots \ldots+A_{p} L^{p}$ and $\mathrm{E}\left(u_{t}\right)=0$ and $\mathrm{E}\left(u_{t} u_{t}^{\prime}\right)=\Sigma_{u}$

Denotes the autoregressive lag order polynomial. Standard estimation methods allow us to obtain consistent estimates of the reduced-form parameters $A_{i}, i=1, \ldots, p$ and the reduced form errors $u t$ and their covariance matrix $\mathrm{E}\left(u_{t} u_{t}^{\prime}\right)=\Sigma \mathrm{u}$ (Kilian, 2011).

\subsection{Data Description and Sources}

The study employs secondary data. The data covers the period of 1986-2012. Annual data on Nominal Effective Exchange Rate Index (NEER), Import Prices (IMP), Interest Rate (ITR), Money Supply (MS) and Inflation (INF) will be sourced from the publication of the Central Bank of Nigeria (CBN) and Oil Price Index (OPI) will be sourced from the World Development Indicators (WDI) published by the World Bank.

\subsection{Estimation Technique}

The study will apply Six-Variable VAR Model to estimate the Impulse Response Function (IRFs) and Variance Decomposition (VDCs) to investigate the impact of Exchange Rate Pass-through (ERPT) to import prices, Inflation, and monetary policy in Nigeria. Use of VAR model helps to account for spurious correlations, and exogeneity bias as it is designed for non-stationary time series and requires no endogenous - exogenous division of variables.

\section{Data Analysis and Interpretation of Results}

\subsection{Test for Stationarity}

Formal testing for stationarity and the order of integration of each variable are undertaken mainly using two standard methods (ADF and PP). Consequently, all series are examined for stationarity using the two test types and the results are summarized in Table 1.

Table 1. Results of the unit root tests based on augmented dickey-fuller test and philip perron test

\begin{tabular}{|c|c|c|c|c|c|}
\hline Variables & \multicolumn{2}{|c|}{ Statistics At Level } & \multicolumn{2}{|c|}{ Statistics At $\mathbf{1}^{\text {st }}$ Difference } & Order of Integration \\
\hline & ADF & PP & ADF & PP & \\
\hline OPI & 1.4830 & 0.8517 & -3.8825 & -8.1358 & $\mathrm{I}(1)$ \\
\hline NEER & -0.5039 & -0.4595 & -3.2140 & -4.8046 & $\mathrm{I}(1)$ \\
\hline
\end{tabular}




\begin{tabular}{|c|c|c|c|c|c|}
\hline LIMP & -3.2236 & -4.0213 & -3.3657 & -7.3572 & $\mathrm{I}(0)$ \\
\hline INT & -3.1321 & -3.4353 & -4.1244 & -6.3509 & $\mathrm{I}(0)$ \\
\hline MS & -3.7693 & -3.0466 & -3.1863 & -3.2398 & $\mathrm{I}(0)$ \\
\hline INF & -3.0574 & -2.5907 & -6.0988 & -4.4104 & $\mathrm{I}(0)$ \\
\hline \multicolumn{7}{|c|}{ TEST CRITICAL VALUES } \\
\hline \multicolumn{7}{|c|}{ AT 1 ${ }^{\text {ST }}$ DIFFERENCE } \\
\hline \multicolumn{7}{|c|}{ AT LEVEL } & ADF & PP \\
\hline $1 \%$ & ADF & PP & -3.7343 & -3.7204 \\
\hline $5 \%$ & -3.7204 & -3.7076 & -2.9907 & -2.9850 \\
\hline $10 \%$ & -2.9850 & -2.9798 & -2.6348 & -2.6318 \\
\hline
\end{tabular}

As we can see from table 1, each of the two tests shows that two (2) of the variables are not stationary at 5\% level of significance. Hence, we continue the analysis by taking the first difference, so that we may determine in which order the variables become stationary. When we look at the results of ADF and PP tests conducted on the difference of the variables, the null hypothesis of unit root is strongly rejected. The test shows that all variables are stationary at first difference since we failed to reject the null hypothesis of stationarity. Thus we can conclude that all the variables are stationary at first difference.

\subsection{ERPT to Import and Inflation: SVAR Approach}

\subsubsection{ERPT to Import and Inflation: Impulse Response Analysis}

Based on the fact that the model passed important diagnostic tests, we perform impulse response analysis with Cholesky orthogonal shock structure from the estimated baseline model including OPI, MS, NEER, IMP, ITR and INF. Figures 2 and 3 shows the estimated orthogonalized impulse response functions for import and inflation to a one standard deviation innovation in NEER. The accumulated impulse responses (solid line in the Figures) are presented over a time horizon of ten. The dotted line in figures denotes a two standard error confidence band around the estimates.

The impulse response function indicates a moderate degree of ERPT to import prices and a low degree of pass-through to inflation. Figure 2 shows response of import price to one standard innovation in NEER. A positive exchange rate shock (i.e. exchange rate appreciation) results in a decrease in import price for the entire forecast horizon. Concerning the speed of pass-through, import price quickly responds to exchange rate shock. As indicated by the confidence bands, the responses are significantly different both from zero and one, over the whole time horizon considered implying ERPT to import price is incomplete. Figure 3 tracks the pass-through of a one standard deviation shock in the exchange rate into inflation. As we can see from figure 3, the response of inflation to exchange rate shock is low which dies shortly after the $5^{\text {th }}$ period. This implies that ERPT to inflation is low and transitory. 
Response of LIMP to NEER

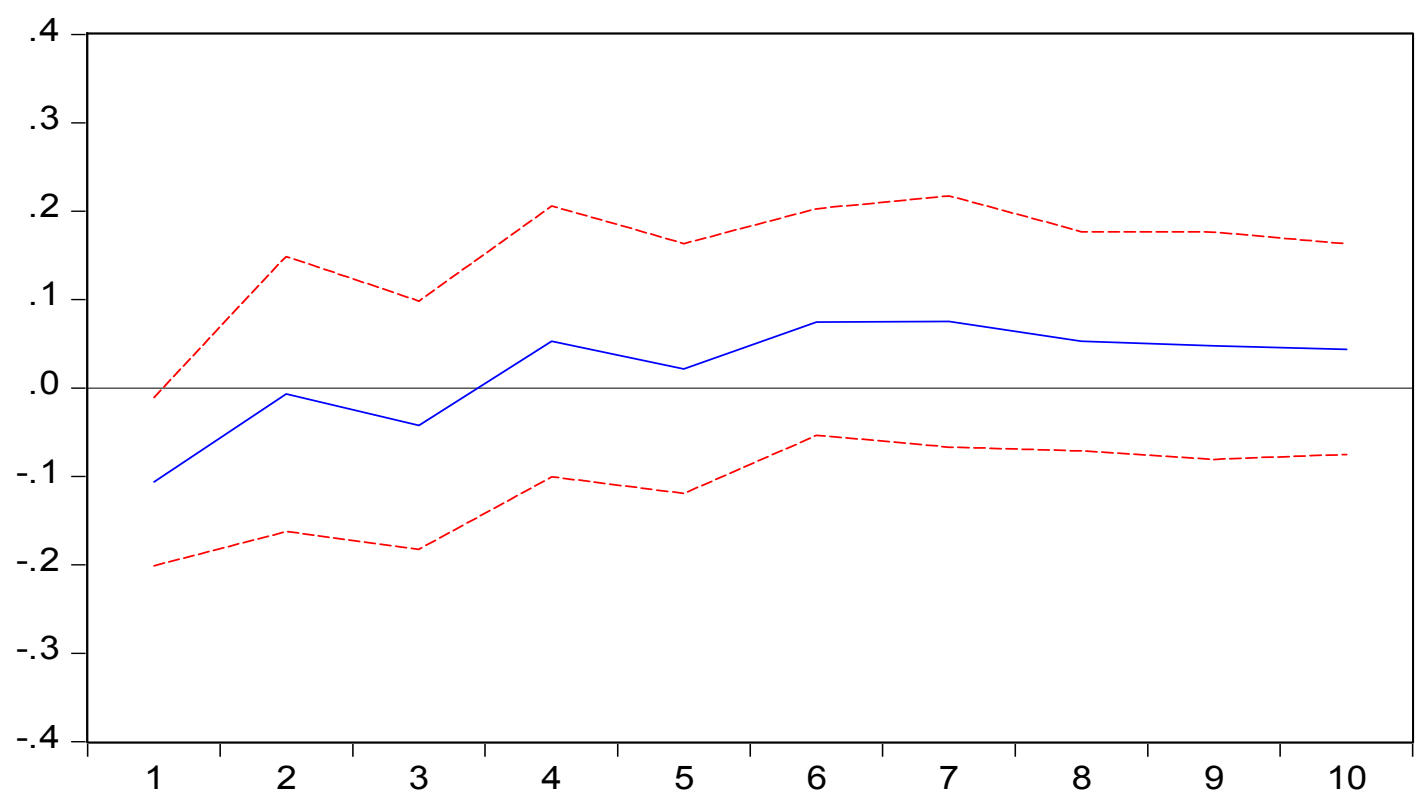

Figure 2. Exchange rate pass-through to import prices

Source: Estimates from E-views (Version 7) Econometric Package.

Response of INF to NEER

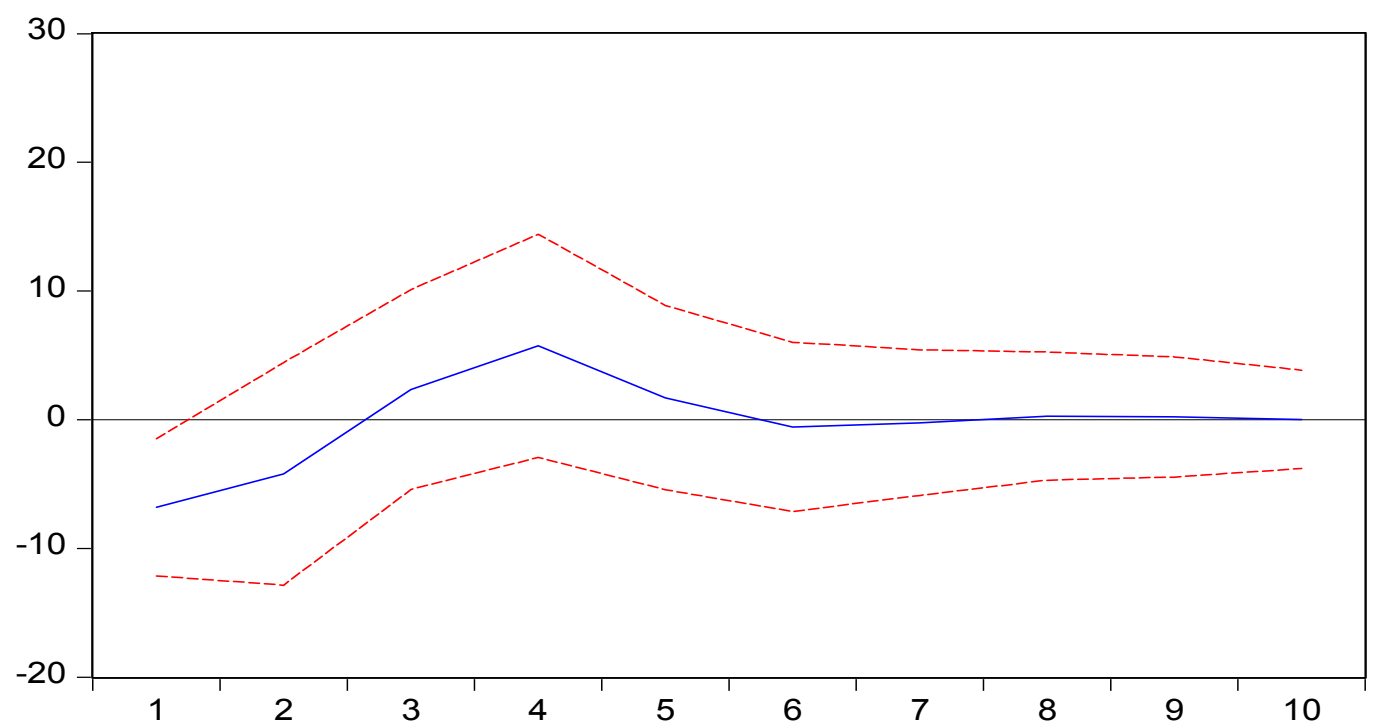

Figure 3. Exchange rate pass-through to inflation

Source: Estimates from E-views (Version 7) Econometric Package. 
Table 2. The response IMP and INF to percentage change in NEER

Table 2a. Response of LIMP

\begin{tabular}{|c|c|c|c|c|c|c|}
\hline Period & OPI & MS & NEER & LIMP & ITR & INF \\
\hline 1 & 0.022134 & 0.112114 & -0.105910 & 0.225791 & 0.000000 & 0.000000 \\
\hline 2 & -0.002794 & -0.085905 & -0.006822 & 0.107381 & -0.044818 & -0.021078 \\
\hline 3 & 0.155084 & -0.041076 & -0.042140 & 0.087381 & 0.072618 & 0.047907 \\
\hline 4 & 0.024166 & 0.035776 & 0.052660 & 0.079068 & 0.023449 & 0.040432 \\
\hline 5 & 0.084577 & 0.094093 & 0.021751 & 0.057545 & 0.043653 & 0.020211 \\
\hline 6 & 0.048838 & 0.073432 & 0.074516 & 0.041058 & 0.062510 & -0.024914 \\
\hline 7 & 0.101030 & 0.012243 & 0.075181 & 0.039305 & 0.028433 & -0.011002 \\
\hline 8 & 0.087769 & -0.000816 & 0.052751 & 0.044959 & 0.011094 & 0.001724 \\
\hline 9 & 0.065510 & 0.014990 & 0.047644 & 0.053296 & -0.012140 & -0.003136 \\
\hline 10 & 0.044863 & 0.027123 & 0.043715 & 0.051758 & -0.012902 & -0.014506 \\
\hline
\end{tabular}

Source: Estimates from E-views (Version 7) Econometric Package.

Table 2b. Response of INF

\begin{tabular}{|c|c|c|c|c|c|c|}
\hline Period & OPI & MS & NEER & LIMP & ITR & INF \\
\hline 1 & -0.456677 & 5.927420 & -6.815986 & 7.045024 & -3.675951 & 9.558248 \\
\hline 2 & -0.325344 & 4.112523 & -4.221846 & 1.755850 & -0.361153 & 4.942241 \\
\hline 3 & 3.009503 & 3.936000 & 2.340736 & -4.403686 & 6.651924 & -1.751993 \\
\hline 4 & 2.422810 & 3.363385 & 5.729724 & -3.947967 & 4.607932 & -2.466822 \\
\hline 5 & 3.311580 & 1.454452 & 1.706333 & -0.881985 & 0.042287 & 0.307954 \\
\hline 6 & 2.220824 & 0.009588 & -0.579409 & 0.231308 & -1.589728 & 0.631472 \\
\hline 7 & 1.438164 & 0.297715 & -0.247995 & -0.159022 & -1.486818 & -0.310634 \\
\hline 8 & 0.350925 & 1.375023 & 0.270787 & -0.039622 & -1.201584 & -0.557871 \\
\hline 9 & -0.003588 & 1.197927 & 0.211123 & 0.508252 & -1.496676 & -0.021464 \\
\hline 10 & 0.181733 & 0.213959 & 0.030764 & 0.395603 & -1.259858 & 0.257866 \\
\hline
\end{tabular}

Source: Estimates from E-views (Version 7) Econometric Package

Table $2 \mathrm{a}$ and $2 \mathrm{~b}$ presents the response of import price and inflation to percentage change in exchange rate. Concerning ERPT to IMP, -0.10 percent of exchange rate shock is passed-through to import price in the $1^{\text {st }}$ period, by -0.04 percent in the 3 rd period, and amounts to about 0.04 in the $10^{\text {th }}$ period. This indicates in Nigeria, ERPT to import price is moderate declines slowly to -0.04 and later increases slowly to 0.04 as the estimating horizon increased. For instance, a 100 percent exchange rate appreciation results in a -0.04 percent decrease in import price at the $3^{\text {rd }}$ period and about 0.07 percent increase after 6 periods. This shows that ERPT to import price is low in the case of Nigeria. 


\section{Macrothink

Compared with the ERPT to import prices, pass-through of exchange rate to inflation is low. A one percent positive shock in exchange rate leads to -6.8 percent decline in INF inflation in the $1^{\text {st }}$ period, -4.2 percent decline after one period and become positive of about 5.7 percent in the $4^{\text {th }}$ period (and subsequent periods). The estimated pass-through coefficient is somehow higher compared to the previous studies on the subject. In this study, even if the degree of pass-through to INF is low, it is significantly different from zero up to one period. This difference could be partly caused by different estimation methodology and partly due to different sample size used.

The low ERPT to consumer prices suggests that inflation is most likely affected by other factors than the exchange rate in Nigeria. Among the variables included in our model, consumer price responds significantly to shocks in oil price index, money supply and shock to INF itself. For instance, increase (positive shock) in OPI results in significant increase in inflation implying that the country is vulnerable to international price shocks (imported inflation). Also inflation shows significant response to Ms after three periods and in all subsequent periods. Furthermore, the significant and persistent response of inflation to its own shock shows the existence of adaptive expectation and inflation inertia.

\subsection{The Relative Importance of Exchange Rate and Other Shocks for Variation in IMP and INF}

While impulse response functions provide information on the size and speed of the pass-through, they give no information on the importance of the respective shocks for the variance of the price indices. In contrast, variance decompositions (VD) indicate the percentage contribution of the different shocks to the variance of each period ahead forecast errors of the variables. Hence, the relative importance of different shocks for the development of the price indices may be assessed using VD analysis.

The results of the VD analysis complement the results from the impulse response analysis. Since our main objective is to analyze the degree of ERPT to import and inflation, Table $3 a$ and $3 \mathrm{~b}$ report the VD results for IMP and INF. This study use Cholesky decomposition similar to impulse response. Furthermore, the estimation applies Cholesky ordering of:

$$
\Delta \mathrm{OPI} \rightarrow \Delta \mathrm{MS} \rightarrow \mathrm{NEER} \rightarrow \Delta \mathrm{LIMP} \rightarrow \mathrm{ITR} \rightarrow \Delta \mathrm{INF}
$$

\subsection{Variance Decomposition Analysis}

4.4.1 The Relative Importance of Exchange Rate and Other Shocks to Variation in IMP and INF 
Table 3a. Variance decomposition of LIMP

\begin{tabular}{|c|c|c|c|c|c|c|c|}
\hline Period & S.E. & OPI & MS & NEER & LIMP & ITR & INF \\
\hline 1 & 0.274332 & 0.650983 & 16.70203 & 14.90451 & 67.74247 & 0.000000 & 0.000000 \\
\hline 2 & 0.310927 & 0.514838 & 20.63525 & 11.65067 & 64.66193 & 2.077754 & 0.459558 \\
\hline 3 & 0.373354 & 17.61117 & 15.52187 & 9.354176 & 50.32352 & 5.224046 & 1.965209 \\
\hline 4 & 0.390470 & 16.48414 & 15.03042 & 10.37090 & 50.10891 & 5.136749 & 2.868885 \\
\hline 5 & 0.417818 & 18.49439 & 18.19874 & 9.328670 & 45.66071 & 5.577900 & 2.739600 \\
\hline 6 & 0.440586 & 17.86105 & 19.14430 & 11.24990 & 41.93191 & 7.029293 & 2.783540 \\
\hline 7 & 0.461085 & 21.10926 & 17.55039 & 12.93046 & 39.01298 & 6.798438 & 2.598469 \\
\hline 8 & 0.474588 & 23.34537 & 16.56623 & 13.44059 & 37.72204 & 6.471733 & 2.454032 \\
\hline 9 & 0.484786 & 24.19956 & 15.97218 & 13.84692 & 37.36026 & 6.265024 & 2.356055 \\
\hline 10 & 0.492679 & 24.25958 & 15.76758 & 14.19410 & 37.27642 & 6.134471 & 2.367857 \\
\hline
\end{tabular}

Source: Estimates from E-views (Version 7) Econometric Package

Table 3b. Variance decomposition of INF

\begin{tabular}{|c|c|c|c|c|c|c|c|}
\hline Period & S.E. & OPI & MS & NEER & LIMP & ITR & INF \\
\hline 1 & 15.37223 & 0.088256 & 14.86816 & 19.65999 & 21.00346 & 5.718279 & 38.66184 \\
\hline 2 & 17.28547 & 0.105226 & 17.41946 & 21.51417 & 17.64310 & 4.566137 & 38.75191 \\
\hline 3 & 19.88783 & 2.369381 & 17.07582 & 17.63746 & 18.23088 & 14.63650 & 30.04996 \\
\hline 4 & 22.10074 & 3.120433 & 16.14348 & 21.00358 & 17.95385 & 16.19928 & 25.57937 \\
\hline 5 & 22.47912 & 5.186529 & 16.02322 & 20.87864 & 17.50847 & 15.65888 & 24.74426 \\
\hline 6 & 22.66182 & 6.063607 & 15.76592 & 20.60872 & 17.23772 & 15.89951 & 24.42453 \\
\hline 7 & 22.76200 & 6.409552 & 15.64454 & 20.43957 & 17.09119 & 16.18653 & 24.22862 \\
\hline 8 & 22.84628 & 6.385945 & 15.89157 & 20.30310 & 16.96563 & 16.34394 & 24.10982 \\
\hline 9 & 22.93319 & 6.337640 & 16.04421 & 20.15799 & 16.88640 & 16.64623 & 23.92753 \\
\hline 10 & 22.97436 & 6.321204 & 15.99543 & 20.08599 & 16.85559 & 16.88734 & 23.85445 \\
\hline
\end{tabular}

Source: Estimates from E-views (Version 7) Econometric Package

The VD analysis for IMP shows that in the first quarter, a shock to the exchange rate contributes 14.9 percent variation to the IMP series, while the Ms and ITR has only 16.7 and 0.00 percent contributions respectively. After first period, the contribution of exchange rate decreases to 9.3 percent in period five, while that of money supply and interest rate increases to 18.1 and 5.5 percent respectively. OPI contributes 0.65 percent of the variation in IMP in the first period while its contribution increases to around 18.4 percent in the fifth period. IMP contributes much for its own variation which amounts to be 67.7 percent in the first period and it becomes around 37.2 percent as the forecast horizon is extended. (See table 3a).

Table $3 \mathrm{~b}$ shows that the exchange rate has 19.6 percent contribution to the variation in INF in the first period and increase to 21.0 percent in the fourth period and declined slightly to 20.0 
in the tenth period in the forecast horizon respectively. The contribution of exchange rate in the variation of INF is high compared to its contribution in the variation of IMP which is consistent with the impulse response result. Money supply contributes only 14.8 percent in the first period to the variation in INF and increased to 16.1 in the fourth period ahead in the forecast horizon. This slightly increases to 15.9 percent in the tenth period. ITR contributes 5.7 percent of the variation in INF in the first period while its contribution increases to 16.8 percent in the tenth period. The significant contribution of ITR to variation in inflation indicates that domestic structural factors have significant effect on inflation than movements in exchange rate. We also found that OPI have a significant contribution to the variation of INF inflation. It has zero percent of the variation in INF in the first period and increases to 6.3 percent in the $10^{\text {th }}$ period ahead. This shows the existence of significant imported inflation to consumer prices. Lastly, inflation explains 38.6 percent of its own variation at the first period, 25.5 percent after three periods and 23.8 percent in the tenth period. This indicates that increase in consumer prices is mainly attributed to its own variations; this suggests that the inflation process in Nigeria has significant inertia.

\section{Conclusions and Recommendations}

This study has established the transmission mechanism through which exchange rate impulses to domestic inflation: (1) a direct effect through prices of imported goods on the Consumer Price Index (CPI); (2) an effect through prices of imported intermediate goods; and (3) an effect through price setting and expectations which includes the expected responses of monetary policy. In addition, the monetary authorities tend to see the exchange rate as one of the major channels of the monetary transmission mechanism through which exchange rate affects domestic inflation especially for small open economies such as Nigeria. It is extremely relevant for the policy maker to assess to what extent the domestic inflation is affected by the exchange rate. To this fact, ERPT was found in this study to be incomplete and has useful implication to policymakers, especially in the design and implementation of exchange rate and monetary policy.

Based on the fact that the concept of ERPT has important implications for exchange rate and monetary policy, the finding that ERPT to import prices is incomplete in Nigeria has important implication about the effectiveness of exchange rate measures which are intended to improve the country's trade balance. Specifically, devaluation measures which are taken to correct trade balance might not be effective to the extent they are expected due to incomplete response of import price (and the resulting change in domestic demand) to exchange rate movements. This means if import prices are less responsive to movements in the exchange rate, the "expenditure-switching" effects might be dampened. Thus policy makers should take into account the incomplete response of import prices when they decide to devalue the currency so as to improve trade balance irrespective of several other factors which might determine the effectiveness of exchange rate policy (such as supply factors, elasticity of foreign and domestic demand, availability of substitutes etc ).

Since one of the mandates of the Central Bank of Nigeria (CBN) is to stabilize inflation in the country, hence, the government should work on changing the attitude of the citizens about 
high price expectations by avoiding abrupt policy changes. To achieve this, the increased role of CBN will definitely require a carefully developed monetary policy and a strengthening of its institutional capacity.

\section{References}

Akofio-Sowah, N. (2009). Is There a Link Between Exchange Rate Pass-Through and the Monetary Regime: Evidence from Sub-Saharan Africa and Latin America. International Advances in Economic Research, 15(3), 296-309. http://dx.doi.org/10.1007/s11294-009-9209-8

Aliyu, S. U. R., Yakub, M. U., Sanni, G. K., \& Duke, O. O. (2008). Exchange Rate Pass-through in Nigeria: Evidence from a Vector Error Correction Model. Central Bank of Nigeria.

Anderton, R. (2003). Extra-Euro Area Manufacturing Import Prices and Exchange Rate Pass-Through. ECB Working Paper No. 219.

Barhoumi, K. (2006). Differences in Long Run Exchange Rate Pass-Through into Import Prices in Developing Countries: An Empirical Investigation. Economic Modelling, 23, 926-951.

Barhoumi, K. (2007). Exchange rate pass-through and structural macroeconomics shocks in developing countries: An empirical investigation. GREQAM, Banque de France.

Bussière, M. (2007). Exchange Rate Pass-through to Trade Prices: The Role of Non-Linearities and Asymmetries. European Central Bank. Working Paper Series No. 822.

Ca' Zorzi, M., Hahn, E., \& Sanchez, M. (2007). Exchange Rate Pass-Through in Emerging Markets. ECB Working Paper No. 739.

Campa, J., \& Goldberg, L. (2002). Exchange Rate Pass-Through into Import Prices: A Macro or Micro Phenomenon? NBER Working Paper No. 8934.

Central Bank of Nigeria (CBN). (n.d.). Annual report and statement of account (1986-2012) Central Bank of Nigeria (CBN). Economic and Financial Review.

Choudhri, E., \& Hakura, D. (2001). Exchange Rate Pass-Through to Domestic Prices: Does the Inflationary Environment Matter? IMF Working Paper No.194.

Clarida, R., Gali, J., \& Gertler, M. (1998). Monetary Policy rules in Practice; some international evidence. European Economic Review, 42, 1033-1067. http://dx.doi.org/10.1016/S0014-2921(98)00016-6

Devereux, M., \& Yetman, J. (2002). Price-Setting and Exchange Rate Pass-Through: Theory and Evidence (pp. 347-371). In Price Adjustment and Monetary Policy, Proceedings of a conference held at the Bank of Canada. Ottawa: Bank of Canada.

Fatai, M. O. (2014). Exchange Rate Pass-through to Import Prices, Inflation and Monetary 
policy in Nigeria. Unpublished M.Sc thesis in the Department of Economics, Obafemi Awolowo University, Ile-Ife, Nigeria.

Federal Republic of Nigeria. (1986). Structural Adjustment Programme for Nigeria. July 1986 June, 1988, Lagos Nigeria.

Feenstra, R. (1989). Symmetric Pass-Through of tariffs and exchange rate Under Imperfect Competition: An Empirical Test. Journal of International Economics, 27(1-2), 25-45. http://dx.doi.org/10.1016/0022-1996(89)90076-7

Gagnon, J., \& Ihrig, J. (2004). Monetary policy and exchange rate pass-through. International Journal of Finance and Economics, 9, 315-338. http://dx.doi.org/10.1002/ijfe.253

Garcia, C. J., \& Restrepo, J. E. (2001). Price Inflation and Exchange Rate Pass-Through in Chile. Central Bank of Chile Working Paper No 128.

Goldberg, P. K., \& Knetter, M. M. (1997). Goods Prices and Exchange Rates: What Have We Learned? Journal of Economic Literature, 35(3), 1243-1272.

Hooper, P., \& Mann, C. (1989). Exchange Rate Pass-Through in the 1980s: The Case of US Imports of Manufactures. Brookings Papers of Economic Activity, 1(3), 297-337. http://dx.doi.org/10.2307/2534500

Ito, T., \& Sato, K. (2006). Exchange Rate Changes and Inflation in Post-Crisis Asian Economies: VAR Analysis of the Exchange Rate Pass-Through. Research Institute of Economy, Trade and Industry Discussion Paper Series No. 018.

Ito, T., \& Sato, K. (2007). Exchange Rate Pass-Through and Domestic Inflation: A comparison between East Asia and Latin American Countries. Research institute of Economy, Trade and Industry, RIETI Discussion Papers, 07040.

Kiptui, M., Ndolo, D., \& Kaminchia, S. (2005). Exchange Rate Pass-Through: To What Extent Do Exchange Rate Fluctuations Affect Import Prices and Inflation in Kenya? Central Bank of Kenya Policy Discussion Paper No. 1.

Krugman, P., \& Obstfeld, M. (2003). International Economics: Theory and Policy (6th ed.). Pearson Education, Inc.

Mann, C. L. (1986). Prices, Profit Margins, and Exchange Rates. Federal Reserve Bulletin, 72(6), 366-379.

Marazzi, M., Sheets, N., \& Vigfusson, R. (2005). Exchange Rate Pass-through to U.S. Import Prices: Some New Evidence. Board of Governors of the Federal Reserve System, International Finance Discussion Papers No. 833.

McCarthy, J. (1999). Pass-Through of Exchange Rates and Import Prices to Domestic Inflation in Some Industrialized Economies. Bank for International Settlements Working Paper No. 79. 
McCarthy, J. (2000). Pass-Through of Exchange Rates and Import Prices to Domestic Inflation in Some Industrialized Economies. Federal Reserve Bank of New York Staff reports No.11. http://dx.doi.org/10.2139/ssrn.249576

Menon, J. (1993). Exchange Rate Pass-Through: Australian Imports of Motor vehicles. International Economic Journal, 7, 1-17. http://dx.doi.org/10.1080/10168739300080023

Menon, J. (1995). Exchange Rate Pass-Through. Journal of Economic Surveys, 9, 197-231. http://dx.doi.org/10.1111/j.1467-6419.1995.tb00114.x

Mumtaz, H., Oomen, Ö., \& Wang, J. (2006). Exchange rate pass-through into UK import prices. Bank of England Working Papers, 312, Bank of England. http://dx.doi.org/10.2139/ssrn.965463

Obstfeld, M., \& Rogoff, K. (1995). Exchange rate dynamics redux. Journal of Political Economy, 103(3), 624-660. http://dx.doi.org/10.1086/261997

Oladipo, O. (2007). Exchange rate pass-Through: A case study of a small open economy. Global Economy journal, 7(3). http://dx.doi.org/10.2202/1524-5861.1246

Oladipo, O. (2012). An analysis of sectoral exchange rate pass-through effects on a small open economy using Leontief Input-output technique. International Journal of Economic Policy in Emerging Economies, 5(1). http://dx.doi.org/10.1504/IJEPEE.2012.045435

Stock, J., \& Watson, M. (2001). Vector Autoregressions. Journal of Economic Perspectives, 15(4), 101-115. http://dx.doi.org/10.1257/jep.15.4.101

Taylor, J. (2000). Low Inflation, Pass-Through, and the Pricing Power of Firms. European Economic Review, 44(7), 1389-1408. http://dx.doi.org/10.1016/S0014-2921(00)00037-4

World Bank. (1994). Nigeria: Structural Adjustment Programme: Policies, implementation and impact. Report No. 13054-UNI, May.

World Bank's World Development Report. (2010). Gross National Income Per Capita. Atlas method and PPP, July, 2011.

\section{Copyright Disclaimer}

Copyright for this article is retained by the author(s), with first publication rights granted to the journal. This is an open-access article distributed under the terms and conditions of the Creative Commons Attribution license (http://creativecommons.org/licenses/by/3.0/). 